\title{
PENGEMBANGAN KOMIK EDUKASI SEBAGAI MEDIA PEMBELAJARAN LITERASI KEUANGAN UNTUK SISWA SEKOLAH DASAR
}

\section{DEVELOPING EDUCATIONAL COMIC AS FINANCIAL LITERACY LEARNING MEDIA FOR ELEMENTARY STUDENTS}

\author{
Oleh: \\ Sarivatul Ilyana \\ Prodi Pendidikan Akuntansi Universitas Negeri Yogyakarta \\ sariyatulilyana@gmail.com \\ Ratna Candra Sari \\ Staf Pengajar Jurusan Pendidikan Akuntansi Universitas Negeri Yogyakarta
}

\begin{abstract}
Abstrak
Penelitian ini bertujuan untuk: mengembangkan komik edukasi "Impian Moni" sebagai media pembelajaran literasi keuangan kompetensi anggaran pribadi untuk siswa sekolah dasar; mengetahui kelayakan komik edukasi'Impian Moni"; mengetahui peningkatan pemahaman siswa mengenai pembelajaran literasi keuangan kompetensi anggaran pribadi dengan menggunakan komik edukasi "Impian Moni". Penelitian ini menggunakan metode Research and Development (R\&D) model Four$D$. Hasil penelitian menunjukkan empat tahap dalam pengembangan komik edukasi: 1) Define, 2) Design 3) Develop,dan 4) Disseminate. Berdasarkan penilaian ahli materi, ahli media, ahli bahasa, dan praktisi, skor rata-rata aspek materi adalah sebesar 4,26 (Sangat Layak), aspek media sebesar 3,56 (Layak), dan aspek bahasa sebesar 3,89 (Layak). Berdasarkan respon siswa pada uji pengembangan menunjukkan bahwa rata-rata skor aspek materi sebesar 4,10 (Layak), aspek media sebesar 3,89 (Layak), dan aspek bahasa sebesar 4,25 (Sangat Layak). Nilai gain peningkatan pemahaman siswa dengan menggunakan komik edukasi "Impian Moni" adalah sebesar 0,37. Berdasarkan kriteria nilai Gain menurut Hake menunjukkan bahwa peningkatan pemahaman siswa tergolong Sedang.
\end{abstract}

Kata kunci: Media Pembelajaran, Literasi Keuangan, Anggaran Pribadi, Komik Edukasi

\begin{abstract}
This research aimed to: develop educational comic "Impian Moni" as a financial literacy media learning in personal budgeting competence for elementary students; assess the feasibility of educational comic "Impian Moni" as a financial literacy media learning; determine the increase of comprehending the financial literacy learning in personal budgeting competence by using educational comic "Impian Moni". The method of this reseach is Research and Development (R\&D) which applied in Four-D model. The result of this research showed that there are four steps to develop the educational comic: 1) Define, 2) Design, 3) Develop, and 4) Disseminate.Based on the assessment of material, media, and languange experts, also a practitioner, the average score in material aspect was 4,26 (Very Worthy), media aspect was 3,56 (Worth), and language aspect was 3,89 (Very Worth). Based on the student responses, the average score of material aspect was 4,10 (Worth), media aspect was 3,89 (Worth), and language aspect was 4,25 (Very Worth). The gain of the increase of student's comprehension by using educational comic "Impian Moni" was 0,37 value. Based on Hake'scriteria gained value, the increase of student's comprehension was classified as medium.
\end{abstract}

Keywords: Learning Media, Financial Literacy, Personal Budgeting, Educational Comic 


\section{PENDAHULUAN}

Di era globalisasi seperti sekarang ini, masyarakat perlu memiliki literasi keuangan yang memadai. Orton (2007) menyatakan bahwa literasi keuangan tidak dapat dipisahkan dalam kehidupan seseorang karena literasi keuangan digunakan oleh individu tersebut untuk melakukan pengambilan keputusan keuangan pribadi. Berdasarkan penelitian yang dilakukan oleh para peneliti di United Kingdom, USA, Australia, Canada, dan OECD diperoleh bahwa terdapat beberapa faktor yang menunjukkan pentingnya literasi keuangan bagi masyarakat yaitu keadaan demografi yang berubah, sektor keuangan yang tumbuh secara kompleks, menurunnya tabungan dan meningkatnya utang, dan sumber daya pemerintah yang terbatas.

Literasi keuangan merupakan proses memahami informasi keuangan, memahami bacaan, dan kemampuan berhitung yang berkaitan dengan keuangan. Warga negara yang memiliki kompetensi keuangan berperan penting dalam kelancaran fungsi pasar keuangan dan stabilitas ekonomi bangsa. (OECD, 2005). Penelitian yang dilakukan oleh Leora, Lusardi, dan Panos (2012) menunjukkan bahwa literasi keuangan memiliki hubungan positif yang signifikan terhadap partisipasi masyarakat di pasar keuangan dan memiliki hubungan negatif terkait dengan penggunaan dana pinjaman. Selain itu, individu dengan tingkat literasi keuangan yang tinggi memiliki tingkat tabungan yang tinggi dan konsumsi yang rendah. Kesimpulan akhir yang diperoleh dari penelitian tersebut adalah literasi keuangan yang tinggi dapat membantu individu menghadapi ketidakpastian kondisi makro ekonomi dan income shock.
Berdasarkan survei nasional literasi keuangan nasional yang dilakukan oleh Otoritas Jasa Keuangan (OJK) pada tahun 2013, tingkat literasi keuangan masyarakat Indonesia sebesar 21,8\% (OJK, 2015). Rendahnya tingkat literasi keuangan masyarakat ini menunjukkan bahwa kemampuan masyarakat dalam membuat pengelolaan dan pembuatan keputusan keuangan masih rendah. Ketidakmampuan masyarakat membuat keputusan keuangan dalam mengelola keuangannya dapat menimbulkan dampak negatif pada seluruh aspek perekonomian suatu negara (Mandell dan Klien, 2009).

Rendahnya kemampuan masyarakat dalam mengelola keuangan dapat diatasi melalui pendidikan literasi keuangan. Pendidikan literasi keuangan merupakan salah satu metode yang mampu meningkatkan kemampuan individu dalam literasi keuangan (Huston, 2010; Hung, Parker \& Yoong, 2009). Pendidikan literasi keuangan merupakan proses peningkatan pemahaman masyarakat mengenai produk dan konsep keuangan melalui informasi, panduan, dan nasehat untuk mengembangkan kemampuan dan kepercayaan masyarakat agar memiliki kesadaran dalam menghadapi risiko dan peluang keuangan, membuat keputusan keuangan, mengetahui kemana memperoleh bantuan, dan perilaku lainnya yang mampu meningkatkan kesejahteraan keuangan masyarakat (OECD, 2005).

Beberapa ahli keuangan
merekomendasikan agar pendidikan keuangan diberikan sejak dini (Mandell, 2009). Pengetahuan literasi keuangan yang diajarkan sejak dini akan terakumulasi hingga dewasa. Pengetahuan literasi keuangan tersebut akan memberikan dampak pada meningkatnya kemampuan mengelola 
keuangan, membuat keputusan keuangan yang lebih bijaksana, merencanakan pembelian, mempunyai kebiasaan menabung, dan menurunkan tingkat kecenderungan korupsi. Suiter dan Meszaros (2005) juga menunjukkan bahwa anak-anak dapat memperoleh manfaat dari pendidikan keuangan, yaitu anak-anak dapat mengendalikan diri agar tidak menghabiskan uangnya untuk berbelanja mengikuti tren mode dan iklan.

Pendidikan literasi keuangan dapat dilakukan di sekolah karena sekolah memiliki peran penting dalam memberikan pendidikan keuangan (Atkinson, Mc.Kay, Kempson \& Collard, 2006; Mandell, 2009). Negara-negara di dunia sedang gencar untuk menerapkan pendidikan literasi keuangan. Beberapa negara yang sudah menerapkan pendidikan literasi keuangan diantaranya adalah Australia, Austria, Chili, Jerman, Irlandia, Italia, Jepang, Belanda, Selandia Baru, Polandia, Rusia, Swedia, Inggris, dan Amerika Serikat (Fraczek, 2014). Beberapa lembaga pun dibentuk untuk memberikan pendidikan literasi keuangan seperti Child and Youth Finance International, Council for Economic Education, Jumpstart (Financial Smart for Student), Practical Money Skills, Money Savvy Generation, dan lembaga pendidikan literasi keuangan lainnya. Akan tetapi, di Indonesia pendidikan literasi keuangan belum mendapatkan perhatian. Pendidikan keuangan masih jarang ditemui baik di sekolah dasar maupun perguruan tinggi.

Saat ini, pendidikan literasi keuangan sedang dikembangkan di Indonesia. Beberapa sekolah dasar di Yogyakarta menjadi sekolah yang digunakan untuk pilot project pendidikan literasi keuangan di Indonesia. Berdasarkan observasi yang dilakukan oleh tim riset LPDP UNY pada tanggal 2-8 November 2015 di tiga Sekolah Dasar, yaitu SD Muhammadiyah Sapen, SD Muhammadiyah Pakel, dan SD Muhammadiyah Jogokariyan ditemukan bahwa 10 dari 18 guru yang mengajarkan literasi keuangan atau $62,5 \%$ guru merasa kesulitan mengajarkan materi literasi keuangan. Hal ini ditunjukkan dari cara guru menyampaikan materi kepada siswa yang tidak begitu jelas dan guru kesulitan memberikan contoh konkret literasi keuangan dalam kehidupan sehari-hari. Kesulitan guru ini disebabkan karena pembelajaran literasi keuangan merupakan pembelajaran yang cukup baru untuk diterapkan di SD.

Seperti halnya proses pembelajaran pada umumnya, proses pembelajaran literasi keuangan dapat dimudahkan dengan menggunakan media pembelajaran. Menurut Dina Indriana (2011) Media pembelajaran adalah semua bahan dan alat fisik yang dapat digunakan untuk mengimplementasikan pembelajaran dan memfasilitasi prestasi siswa terhadap sasaran atau tujuan pembelajaran. Penggunaan media pembelajaran dalam proses belajar mengajar dapat mengkonkretkan berbagai konsep yang abstrak. Konsep-konsep yang dirasa abstrak dan sulit dijelaskan secara langsung kepada siswa bisa dikonkretkan atau disederhanakan melalui pemanfaatan media pembelajaran. Berdasarkan observasi yang dilakukan, media pembelajaran yang dapat mendukung pembelajaran literasi keuangan masih terbatas.

Salah satu media pembelajaran yang dapat digunakan untuk pembelajaran literasi keuangan adalah komik edukasi. Komik edukasi adalah salah satu jenis komik yang kini sedang berkembang di masyarakat. Salah satu keunikan jenis komik ini adalah selain memiliki konten cerita dan narasi 
komik pada umumnya, komik edukasi juga memiliki konten edukasi dan informasi terkait subjek pelajaran yang disampaikannya, sehingga cocok digunakan untuk media pembelajaran. Jenis komik ini juga telah mendapat pengakuan sebagai alat pembelajaran di sekolah di negara Korea Selatan (Chung Ah Young, 2010), dan jenis komik tersebut juga mulai banyak digunakan sebagai media pembelajaran di Amerika (Cary, 2004).

Berdasarkan permasalahan yang telah diuraikan di atas, maka peneliti melakukan penelitian pengembangan yang berjudul Pengembangan Komik Edukasi "Impian Moni” sebagai Media Pembelajaran Literasi Keuangan Kompetensi Anggaran Pribadi bagi Siswa Sekolah Dasar. Tujuan dari penelitian ini adalah untuk mengembangkan komik edukasi, mengetahui kelayakan komik edukasi, dan mengetahui peningkatan pemahaman siswa Sekolah Dasar dengan menggunakan komik edukasi yang dikembangkan. Dengan adanya penelitian ini diharapkan produk yang dihasilan dapat dimanfaatkan untuk pembelajaran literasi keuangan.

\section{METODE PENELITIAN}

Jenis Penelitian

Penelitian ini merupakan jenis penelitian dan pengembangan (Research and Development).

\section{Waktu dan Tempat Penelitian}

Penelitian ini dilaksanakan di kelas IV SD Muhammadiyah Pakel yang beralamat di Jl. Pakel Baru No. 40 Umbulharjo, Kota Yogyakarta, DIY. Penelitian ini dilaksanakan secara bertahap dari bulan November 2015 hingga Maret 2016.

\section{Target/Subjek Penelitian}

Subjek yang akan digunakan dalam penelitian ini adalah subjek uji pengembangan dan subjek uji validasi yang terdiri dari 42 siswa kelas IV SD Muhammadiyah Pakel.

\section{Prosedur Penelitian Pengembangan}

Pada penelitian ini, peneliti menggunakan model pengembangan Four-D yang dikembangkan oleh Thiagarajan dan Semmel (1974). Menurut Rochmad (2012) terdapat empat tahap dalam pengembangan model ini, yaitu define, design, develop, dan disseminate. Prosedur pengembangan dapat dilihat pada gambar 1 .

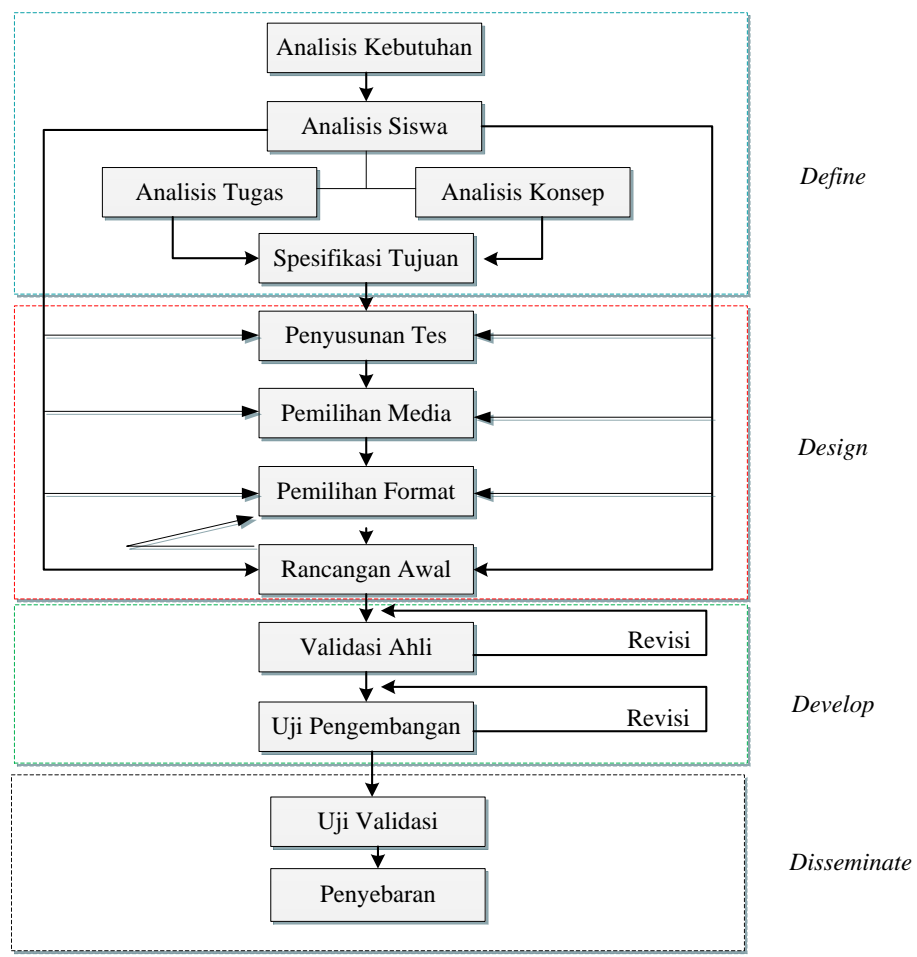

\section{Gambar 1. Prosedur Pengembangan}

a. Tahap Definisi (Define)

1) Analisis kebutuhan

Meliputi analisis masalah mendasar yang dihadapi dalam pembelajaran literasi keuangan.

2) Analisis siswa

Meliputi analisis terhadap 
siswa dengan mempertimbangkan ciri, kemampuan, dan pengalaman siswa, baik sebagai kelompok maupun individu. Analisis siswa meliputi kemampuan akademik, kemampuan ekonomi, usia, dan tingkat kedewasaan.

3) Analisis tugas

Analisis ini meliputi analisis struktur isi, analisis prosedural, analisis proses informasi, analisis konsep, dan perumusan tujuan.

4) Analisis konsep

Analisis ini dilakukan untuk memilih, merinci, dan menetapkan secara sistematis konsep yang relevan yang akan diajarkan berdasarkan analisis kebutuhan.

5) Spesifikasi tujuan

Analisis ini dilakukan untuk merumuskan hasil analisis konsep dan analisis tugas.

b. Tahap Desain (Design)

Pada tahap ini dilakukan perancangan komik edukasi "Impian Moni”. Tahap ini terdiri dari tiga langkah, yaitu:

1) Penyusunan tes

Tes disusun berdasarkan hasil perumusan tujuan pembelajaran khusus. Tes ini merupakan suatu alat ukur untuk mengukur pemahaman siswa mengenai materi literasi keuangan yang diberikan.

2) Pemilihan media

Pemilihan media dilakukan untuk menentukan media yang tepat dalam penyajian materi pembelajaran yang bersumber dari media dengan landasan bahwa konsep dan prinsip literasi keuangan. Proses pemilihan media disesuaikan dengan analisis yang telah dilakukan.

3) Pemilihan format

Pemilihan format dilakukan dengan memilih format komik edukasi yang akan dibuat. Pemilihan format ini disesuaikan dengan subjek penelitian, yaitu siswa SD.

4) Rancangan awal

Rancangan awal dilakukan dengan menentukan tema, membuat karakter tokoh, membuat story board, dan membuat komik edukasi.

c. Tahap Pengembangan (Develop)

Tahap pengembangan terdiri dari penilaian para ahli dan uji lapangan.

1) Penilaian para ahli

Validator yang digunakan dalam penelitian ini adalah ahli materi, ahli media, dan ahli bahasa yang berkompeten.

2) Uji pengembangan

Uji penembangan dilakukan terhadap 10 siswa SD kelas IV. Uji pengembangan ini digunakan untuk mengetahui respon siswa terhadap komik edukasi.

d. Tahap Penyebaran (Disseminate)

Terdapat dua langkah dalam tahap ini, yaitu:

1) Uji validasi

Sebelum mdia pembelajaran disebarluaskan, maka perlu dilakukan evaluasi atas penggunaan produk. Evaluasi ini merupakan tes pada kelas uji validasi yaitu kelas IV A SD Muhammadiyah Pakel.

2) Penyebaran

Penyebaran merupan proses terakhir dalam penelitian pengembangan ini. Penyebaran 
dilakukan ke sekolah lain.

Data, Instrumen, dan Teknik Pengumpulan

Data yang dikumpulkan dalam penelitian ini mencakup data kualitatif dan kuantitatif, yaitu:

a. Data kualitatif merupakan data tentang proses pengembangan komik edukasi sebagai media pembelajaran literasi keuangan berupa kritik dan saran dari para ahli materi, ahli media, ahli bahasa, dan praktisi.

b. Data kuantitatif merupakan data pokok dalam penelitian yang berupa data penilaian tentang media pembelajaran literasi keuangan dan data uji validasi.

Instrumen pengumpulan data dalam penelitian ini terdiri dari empat jenis, yaitu angket uji validitas instrumen penelitian, angket uji kelayakan, angket respon siswa, dan lembar tes siswa.

a. Data uji kelayakan

Data lembar validasi instrumen, penilaian ahli materi, penilaian ahli media, penilaian ahli bahasa, penilaian guru, dan respon siswa disusun dengan skala interval 1 sampai 5. Analisis data lembar penilaian menggunakan analisis statistik deskriptif dengan langkahlangkah sebagai berikut:

1) Langkah pertama adalah mencari skor rata-rata penilaian produk. Rumus yang digunakan adalah:

$$
\overline{\mathrm{X}}=\frac{\sum \mathrm{x}}{n}
$$

Keterangan:

$$
\begin{array}{ll}
\overline{\mathrm{X}} & : \text { skor rata-rata } \\
\mathrm{n} & : \text { jumlah butir, dan }
\end{array}
$$

$\sum \mathrm{x} \quad$ : jumlah skor butir

2) Nilai rata-rata skor dikonversikan menjadi data kualitatif berupa kriteria kualitas produk. Pedoman konversi ditunjukkan pada tabel 1.

Tabel 1. Kategori Penilaian Skala Lima

\begin{tabular}{|l|l|l|}
\hline Interval Skor & Nilai & Kategori \\
\hline$\overline{\mathrm{X}}>\mathrm{x}_{\mathrm{i}}+1,8 \mathrm{SBi}$ & $\mathrm{A}$ & $\begin{array}{l}\text { Sangat } \\
\text { layak }\end{array}$ \\
\hline $\begin{array}{l}\overline{\mathrm{X}} \mathrm{i}+0,6 \mathrm{SBi}<\overline{\mathrm{X}} \leq \\
\mathrm{x}_{\mathrm{i}}+1,8 \mathrm{SBi}\end{array}$ & $\mathrm{B}$ & Layak \\
\hline $\begin{array}{l}\overline{\mathrm{X}} \mathrm{i}-\mathrm{o}, 6 \mathrm{SBi}<\overline{\mathrm{X}} \leq \\
\mathrm{x}_{\mathrm{i}}+0,6 \mathrm{SBi}\end{array}$ & $\mathrm{C}$ & $\begin{array}{l}\text { Cukup } \\
\text { Layak }\end{array}$ \\
\hline $\begin{array}{l}\overline{\mathrm{X}} \mathrm{i}-1,8 \mathrm{SBi}<\overline{\mathrm{X}} \leq \\
\mathrm{x}_{\mathrm{i}}-0,6 \mathrm{SBi}\end{array}$ & $\mathrm{D}$ & $\begin{array}{l}\text { Kurang } \\
\text { Layak }\end{array}$ \\
\hline$\overline{\mathrm{X}} \leq \mathrm{x}_{\mathrm{i}}-1,8 \mathrm{SBi}$ & $\mathrm{E}$ & $\begin{array}{l}\text { Sangat } \\
\text { Kurang } \\
\text { Layak }\end{array}$ \\
\hline
\end{tabular}

(Sumber: Sukarjo, 2005:53)

Keterangan:

$\overline{\mathrm{X}}$ : Skor aktual

$\mathrm{x}_{\mathrm{i}}$ : rerata skor ideal $=1 / 2$ (skor

maksimal ideal + skor minimal ideal)

SBi : Simpangan baku ideal $=1 / 6$ (skor maksimal ideal - skor minimal ideal)

b. Data penilaian hasil belajar siswa Untuk data hasil belajar siswa (pre-test dan post-test) akan dianalisis dengan menggunakan Paired Sample T-test dan gain test. Analisis Paired Samples T-test dilakukan dengan aplikasi SPSS untuk melakukan uji $\mathrm{T}$ terhadap data pretest dan posttest. Teknik analisis data gain-test dilakukan dengan menghitung nilai gain (g) untuk mengetahui peningkatan pemahaman siswa.

$$
g=\frac{\text { skor posttest }- \text { skor pretest }}{\text { skor maksimum }- \text { skor pretest }}
$$


Berdasarkan hasil perhitungan tersebut, selanjutnya dilakukan interprestasi nilai gain yang ditunjukkan pada tabel 2 .

Tabel 2. Kriteria Nilai Gain

\begin{tabular}{|l|l|}
\hline Nilai $\mathbf{g}$ & Kriteria \\
\hline $\mathrm{g}>0,7$ & Tinggi \\
\hline $0,7<\mathrm{g}<0,3$ & Sedang \\
\hline $\mathrm{g}<0,3$ & Rendah \\
\hline
\end{tabular}

(Sumber: Hake, 2012)

\section{HASIL PENELITIAN DAN PEMBA- HASAN}

Hasil penelitian

Penelitian pengembangan komik edukasi "Impian Moni" sebagai media pembelajaran literasi keuangan dilaksanakan selama 5 bulan terhitung dari bulan November 2015 hingga Maret 2016.

Data hasil penelitian adalah sebagai berikut:

a. Tahap pendefinisian

1) Analisis kebutuhan

Berdasarkan observasi yang dilakukan di kelas IV A SD Muhammadiyah Pakel pada pembelajaran literasi keuangan, konsep literasi keuangan yang disampaikan guru kepada siswa belum jelas dan contoh-contoh literasi keuangan dalam kehidupan sehari-hari juga belum begitu konkret. Media pembelajaran yang dapat digunakan dalam penerapan pembelajaran literasi keuangan ini masih terbatas. Oleh karena itu, perlu dikembangkan media pembelajaran literasi keuangan yang dapat digunakan oleh siswa.

2) Analisis siswa

$$
\text { Pada tahap ini, peneliti }
$$
melakukan survei terhadap jumlah uang saku, kebiasaan penggunaan uang saku, dan rencana penggunaan uag saku.

3) Analisis tugas, analisis konsep, dan spesifikasi tujuan

Standar kompetensi yang digunakan adalah memahami konsep menghasilkan (earning) dan menggunakan (spending) uang dengan bijak. Kompetensi dasar yang digunakan adalah membuat anggaran pribadi. Indikator pencapaian yang akan dicapai adalah:

a) Siswa mampu menjelaskan pengertian anggaran

b) Siswa mampu menjelaskan komponen anggaran pribadi

c) Siswa mampu mejelaskan tujuan pembuatan anggaran pribadi

d) Siswa mampu mengidentifikasi informasi yang ada dalam anggaran pribadi

e) Siswa mampu membuat anggaran pribadi untuk dirinya sendiri.

b. Tahap perancangan (design)

1) Penyusunan tes

Tes dalam penelitian ini digunakan untuk mengukur peningkatan pemahaman siswa..

2) Pemilihan media

Berdasarkan analisis-analisis tersebut, media yang dikembangkan dalam penelitian ini adalah komik edukasi "Impian Moni” sebagai media pembelajaran literasi keuangan kompetensi anggaran pribadi untuk siswa sekolah dasar.

3) Pemilihan format

Komik edukasi "Impian Moni" dibuat dengan membuat ilustrasi yang mampu membantu siswa membaca buku pelajaran, setiap halaman terdapat setengah atau satu halaman penuh gambar disertai petunjuk yang 
jelas, ilustrasi gambar dikaitkan dengan kehidupan nyata, ilustrasi ditata dengan baik, gambar yang dibuat erat kaitannya dengan materi pelajaran dan ukurannya tepat, serta gambar dibuat berwarna.

4) Rancangan awal

Tema komik edukasi ini adalah "Cerdas Mengelola Uang dengan Membuat Anggaran Pribadi". Terdapat tujuh karakter tokoh dalam komik edukasi. Story board yang dibuat berdasarkan tema dan karakter tokoh. Story board yang telah dibuat digunakan untuk acuan membuat rancangan awal komik edukasi.

c. Tahap pengembangan (develop)

1) Validasi instrumen penelitian

Validasi instrumen penelitian digunakan untuk menguji validitas instrumen penilaian para ahli dan respon siswa. hasil validasi instrumen penelitian ditunjukkan pada tabel 3 .

Tabel 3. Hasil Validasi Instrumen Penelitian

\begin{tabular}{|l|l|l|}
\hline No. & \multicolumn{1}{|c|}{ Aspek yang dinilai } & Skor \\
\hline 1. & Aspek isi/materi & 5 \\
\hline 2. & Aspek media & 5 \\
\hline 3. & Aspek Bahasa & 5 \\
\hline 4. & Penilaian respon siswa & 5 \\
\hline Rata-rata skor & 5 \\
\hline
\end{tabular}

Berdasarkan kriteria penilaian skala lima untuk konversi data kuantitatif ke kualitatif, maka instrumen penelitian dinyatakan "Sangat Layak" untuk digunakan tanpa revisi.

2) Validasi ahli

Validasi ahli dilakukan oleh ahli materi, ahli media, ahli bahasa, dan praktisi. Validasi ahli ini menilai aspek materi, media, dan bahasa dalam komik edukasi. Hasil penilaian para ahli ditunjukkan pada tabel 4 , tabel 5 , dan tabel 6.

Tabel 4. Hasil Penilaian Aspek Materi

\begin{tabular}{|c|c|c|c|}
\hline \multirow[b]{2}{*}{ No } & \multirow[b]{2}{*}{ Kriteria } & \multicolumn{2}{|c|}{ Skor } \\
\hline & & $\begin{array}{l}\text { Validasi } \\
\text { ahli } \\
\text { materi }\end{array}$ & $\begin{array}{l}\text { Validasi } \\
\text { praktisi } \\
\text { (guru) }\end{array}$ \\
\hline 1. & $\begin{array}{l}\text { Kejelasan } \\
\text { materi } \\
\text { pembelajaran }\end{array}$ & 5 & 3,67 \\
\hline 2. & $\begin{array}{l}\text { Kesesuaian } \\
\text { komik } \\
\text { edukasi } \\
\text { dengan } \\
\text { tujuan } \\
\text { pembelajaran }\end{array}$ & 5 & 4 \\
\hline 3. & $\begin{array}{l}\text { Kesesuaian } \\
\text { komik } \\
\text { edukasi } \\
\text { dengan } \\
\text { materi } \\
\text { pembelajaran }\end{array}$ & 5 & 4 \\
\hline 4. & $\begin{array}{l}\text { Kesesuaian } \\
\text { komik } \\
\text { edukasi } \\
\text { dengan } \\
\text { tingkat umur } \\
\text { siswa }\end{array}$ & 5 & 3 \\
\hline 5. & $\begin{array}{l}\text { Ketepatan } \\
\text { penggunaan } \\
\text { istilah } \\
\text { keuangan }\end{array}$ & 4 & 4 \\
\hline 6. & $\begin{array}{l}\text { Kemenarikan } \\
\text { komik } \\
\text { edukasi } \\
\text { sebagai } \\
\text { media } \\
\text { pembelajaran }\end{array}$ & 5 & 3,5 \\
\hline & a-rata skor & 4,83 & 3,7 \\
\hline & $\begin{array}{l}\text { a-rata skor } \\
\text { ek materi }\end{array}$ & 4,26 & \\
\hline
\end{tabular}

Pada tabel 4, rata-rata skor aspek materi adalah 4,26. Apabila dikonversikan ke dalam data kualitatif 
berdasarkan kategori penilaian skala lima, maka aspek materi dalam komik edukasi ini dikategorikan "Sangat Layak".

Tabel 5. Hasil Penilaian Aspek Media

\begin{tabular}{|c|c|c|c|}
\hline \multirow[b]{2}{*}{ No } & \multirow[b]{2}{*}{ Kriteria } & \multicolumn{2}{|c|}{ Skor } \\
\hline & & $\begin{array}{l}\text { Validasi } \\
\text { ahli } \\
\text { materi }\end{array}$ & $\begin{array}{l}\text { Validasi } \\
\text { praktisi } \\
\text { (guru) }\end{array}$ \\
\hline 1. & $\begin{array}{l}\text { Ketepatan } \\
\text { ukuran }\end{array}$ & 3,67 & 2,67 \\
\hline 2. & $\begin{array}{l}\text { Ketepatan } \\
\text { penataan } \\
\text { gambar }\end{array}$ & 3,67 & 4 \\
\hline 3. & $\begin{array}{l}\text { Kemenarikan } \\
\text { gambar }\end{array}$ & 3,33 & 2,3 \\
\hline 4. & $\begin{array}{l}\text { Kesederhanaan } \\
\text { media } \\
\text { pembelajaran }\end{array}$ & 4,33 & 3,3 \\
\hline 5. & $\begin{array}{l}\text { Keterpaduan } \\
\text { aspek visual }\end{array}$ & 3 & 5 \\
\hline 6. & $\begin{array}{l}\text { Kesesuaian } \\
\text { gambar atau } \\
\text { ilustrasi } \\
\text { dengan tingkat } \\
\text { umur siswa }\end{array}$ & 3,33 & 2,3 \\
\hline 7. & $\begin{array}{l}\text { Kejelasan alur } \\
\text { cerita }\end{array}$ & 4 & 5 \\
\hline Rat & a-rata skor & 3,61 & 3,51 \\
\hline & $\begin{array}{l}\text { a-rata skor } \\
\text { ek media }\end{array}$ & 3,56 & \\
\hline
\end{tabular}

Pada tabel 5 mengenai hasil penilaian aspek media, rata-rata skor aspek media adalah sebesar 3,56. Apabila dikonversikan ke dalam data kualitatif maka aspek media dalam komik edukasi ini dikategorikan "Layak".

Pada tabel 6 mengenai hasil penilaian aspek bahasa, rata-rata skor aspek bahasa adalah sebesar 3,89. Apabila dikonversikan ke dalam data kualitatif, maka aspek bahasa dalam komik edukasi ini masuk dalam kategori "Layak".

Tabel 6. Hasil Penilaian Aspek Bahasa

\begin{tabular}{|c|c|c|c|}
\hline \multirow[b]{2}{*}{ No. } & \multirow[b]{2}{*}{ Kriteria } & \multicolumn{2}{|c|}{ Skor } \\
\hline & & $\begin{array}{l}\text { Validas } \\
\text { i ahli } \\
\text { materi }\end{array}$ & $\begin{array}{l}\text { Vali } \\
\text { dasi } \\
\text { pra } \\
\text { ktisi } \\
\text { (gur } \\
\text { u) } \\
\end{array}$ \\
\hline 1. & $\begin{array}{l}\text { Kesederhan } \\
\text { aan Bahasa }\end{array}$ & 3,67 & 3,67 \\
\hline 2. & $\begin{array}{l}\text { Kesesuaian } \\
\text { bahasa } \\
\text { dengan } \\
\text { tingkat } \\
\text { umur siswa }\end{array}$ & 4 & 4 \\
\hline 3. & $\begin{array}{l}\text { Kesesuaian } \\
\text { bahasa yang } \\
\text { digunakan } \\
\text { oleh tokoh } \\
\text { dalam } \\
\text { komik } \\
\text { edukasi }\end{array}$ & 4 & 3 \\
\hline 4. & $\begin{array}{l}\text { Penggunaan } \\
\text { bahasa yang } \\
\text { komunikatif }\end{array}$ & 4 & 4 \\
\hline 5. & $\begin{array}{l}\text { Kesesuaian } \\
\text { bahasa yang } \\
\text { digunakan } \\
\text { dengan } \\
\text { EYD }\end{array}$ & 2,67 & 4,67 \\
\hline 6. & $\begin{array}{l}\text { Ketepatan } \\
\text { penggunaan } \\
\text { istilah } \\
\text { dalam } \\
\text { keuangan } \\
\end{array}$ & 4 & 5 \\
\hline \multicolumn{2}{|c|}{ Rata-rata skor } & 3,72 & 4,06 \\
\hline \multicolumn{2}{|c|}{$\begin{array}{l}\text { Rata-rata skor } \\
\text { aspek Bahasa }\end{array}$} & \multicolumn{2}{|l|}{3,89} \\
\hline
\end{tabular}

Hasil penilaian kualitatif yang berupa revisi dan saran digunakan untuk memperbaiki komik edukasi. Hasil revisi ini digunakan untuk uji pengembangan pada siswa. 
3) Uji pengembangan

Tujuan dari dilakukannya uji pengembangan ini adalah untuk mengetahui respon siswa terhadap media pembelajaran komik edukasi. Hasil uji pengembangan ditunjukkan pada tabel 7.

Tabel 7. Hasil Uji Pengembangan

\begin{tabular}{|l|l|l|l|}
\hline No. & Aspek & $\begin{array}{l}\text { Nilai } \\
\text { Rata- } \\
\text { Rata }\end{array}$ & Kriteria \\
\hline 1. & Materi & 4,10 & Layak \\
\hline 2. & Media & 3,89 & Layak \\
\hline 3. & Bahasa & 4,25 & $\begin{array}{l}\text { Sangat } \\
\text { Layak }\end{array}$ \\
\hline
\end{tabular}

d. Tahap penyebaran (disseminate)

1) Uji validasi

Uji validasi dilakukan dengan memberikan pretest dan posttest terhadap subjek uji validasi, yaitu siswa kelas IV A SD Muhammadiyah Pakel. Data uji validasi diuji dengan menggunakan Paired Sample T-test pada program SPSS Statistic 18 dan penghitungan nilai gain.

a) Analisis dan interpretasi output

Paired Samples Statistic

Tabel 8. Paired Samples Statistics

\begin{tabular}{|l|r|r|}
\hline & Mean & \multicolumn{1}{|c|}{ N } \\
\hline Pretest & 4,0156 & 32 \\
Posttest & 6,2500 & 32 \\
\hline
\end{tabular}

Berdasarkan tabel 8 maka dapat dilihat bahwa terdapat kenaikan rata-rata skor pretest dan posttest siswa sebesar 2,14.

b) Analisis dan interpretasi output Paired Samples Test
Tabel 9. Paired Samples Test

\begin{tabular}{|c|c|c|c|}
\hline & t & df & $\begin{array}{c}\text { Sig. (2- } \\
\text { tailed) }\end{array}$ \\
\hline $\begin{array}{l}\text { Pretest }- \\
\text { Posttest }\end{array}$ & $-5,487$ & 31 &, 000 \\
\hline
\end{tabular}

Berdasarkan tabel 9 nilai $\mathrm{t}$ yang diperoleh adalah sebesar 5,487 dengan signifikansi 0,000. Karena nilai signifikansi $<0,05$ maka dapat disimpulkan bahwa terdapat perbedaan antara nilai pretest dan posttest siswa.

c) Analisis nilai gain

Diketahui bahwa rata-rata skor posttest siswa adalah sebesar 6,25, rata-rata skor pretest siswa adalah sebesar 4,0156, dan skor maksimum siswa adalah 10,00. Dari data tersebut, maka perhitungan nilai gain-nya adalah sebagai berikut:

$$
\begin{aligned}
g & =\frac{\text { skor posttest }- \text { skor pretest }}{\text { skor maksimum }- \text { skor pretest }} \\
g & =\frac{6,25-4,0156}{10,00-4,0156} \\
g & =0,37
\end{aligned}
$$

Berdasarkan kriteria nilai gain menurut Hake (2012), maka peningkatan pemahaman siswa mengenai kompetensi anggaran pribadi dengan menggunakan komik edukasi tergolong "Sedang".

2) Penyebaran

Media komik edukasi disebarkan ke sekolah lain, yaitu SD Muhammadiyah Sapen dan SD Muhammadiyah Jogokariyan. Pemilihan sekolah didasarkan pada sekolah yang sudah menerapkan pembelajaran literasi keuangan. 


\section{Pembahasan}

Media komik edukasi "Impian Moni”" sebagai media pembelajaran literasi keuangan kompetensi anggaran pribadi dikembangkan menggunakan model Four-D yang dikembangkan oleh Thiagarajan dan Semmel (1974). Penelitian pengembangan ini dilakukan melalui empat tahap yaitu pendefinisian (define), perancangan (design), pengembangan (develop), dan penyebaran (dissemination).

Uji validasi ahli dilakukan oleh beberapa pihak, yaitu ahli materi, ahli media, ahli bahasa, dan praktisi (guru). Ahli materi menilai aspek materi, ahli media menilai aspek media, ahli bahasa menilai aspek bahasa, dan praktisi menilai seluruh aspek komik edukasi.

Ringkasan hasil penilaian aspek materi, media, dan bahasa dari para ahli dan praktisi dapat dilihat pada tabel 10 .

Tabel 10. Hasil Penilaian Ahli

\begin{tabular}{|l|l|l|l|}
\hline No. & Aspek & $\begin{array}{l}\text { Nilai Rata- } \\
\text { Rata }\end{array}$ & Kriteria \\
\hline 1. & Materi & 4,26 & Sangat Layak \\
\hline 2. & Media & 3,56 & Layak \\
\hline 3. & Bahasa & 3,89 & Layak \\
\hline
\end{tabular}

Komik edukasi yang telah dinilai oleh para ahli kemudian direvisi sesuai komentar dan saran yang diberikan. Hasil komik edukasi yang telah direvisi akan digunakan untuk uji pengembangan pada siswa.

Uji pengembangan dilakukan dengan menggunakan komik edukasi yang telah direvisi. Subjek penelitian dalam uji pengembangan ini adalah 10 siswa kelas IV B SD Muhammadiyah Pakel. Instrumen yang digunakan dalam uji pengembangan adalah kuesioner respon siswa dengan menilai beberapa aspek yaitu aspek isi/materi, aspek media, dan aspek bahasa. Hasil uji pengembangan menunjukkan bahwa rata-rata skor aspek maeri sebesar 4,1 (Layak), aspek media 3,89 (Layak), dan aspek bahasa (Sangat Layak).

Berdasarkan pengamatan yang dilakukan, semua siswa mampu memahami pembelajaran literasi keuangan kompetensi anggaran pribadi yang disajikan dalam komik edukasi "Impian Moni”. Pada aspek media, siswa memiliki respon positif dimana siswa meminta untuk dibuatkan komik edukasi "Impian Moni” seri lainnya. Pada aspek bahasa, siswa mampu memahami bahasa yang digunakan dalam komik edukasi dengan baik. Tidak ada hal yang perlu diperbaiki mengenai komik edukasi "Impian Moni" sehingga komik edukasi ini dapat digunakan untuk uji validasi tanpa revisi.

Pengukuran pemahaman siswa mengenai kompetensi Anggaran Pribadi yang dipelajari melalui komik edukasi "Impian Moni" dapat diukur dengan menggunakan pretest dan posttest. Pengukuran pemahaman ini dilakukan pada saat tahap uji validasi. Berdasarkan data paired samples test, rata-rata skor pretest dan posttest dapat dilihat pada gambar 2 .

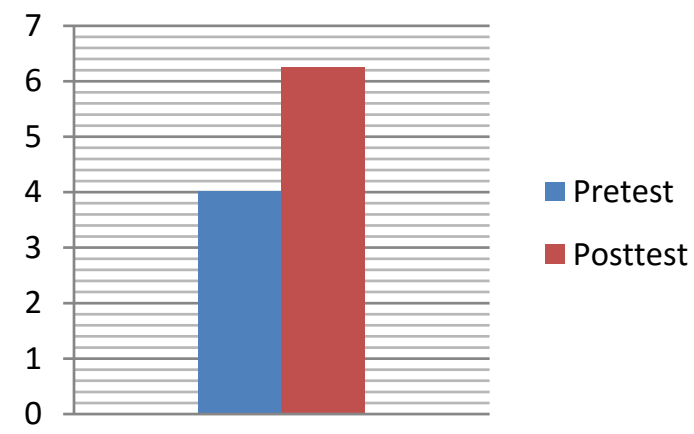

\section{Gambar 2. Grafik Rata-rata Skor Pretest dan Posttest}

Selanjutnya, untuk melihat hasil analisis nilai gain dapat dilihat pada tabel 11. 
Tabel 11. Analisis Nilai Gain

\begin{tabular}{|l|l|l|l|l|}
\hline $\begin{array}{l}\text { Nilai } \\
\text { Gain }\end{array}$ & $\begin{array}{l}\text { Rata- } \\
\text { rata } \\
\text { Nilai } \\
\text { Pretes } \\
\text { t }\end{array}$ & $\begin{array}{l}\text { Rata- } \\
\text { rata } \\
\text { Nilai } \\
\text { Posttes } \\
\text { t }\end{array}$ & $\begin{array}{l}\text { Nilai } \\
\text { Maksimu } \\
\text { m }\end{array}$ & $\begin{array}{l}\text { Nila } \\
\text { i } \\
\text { Gai } \\
\text { nai }\end{array}$ \\
\cline { 2 - 5 } & 4,0156 & 6,25 & 10 & 0,37 \\
\hline
\end{tabular}

Dari tabel 11 diketahui bahwa nilai gain pemahaman siswa mengenai kompetensi anggaran pribadi melalui komik edukasi "Impian Moni" adalah sebesar 0,37. Berdasarkan kriteria nilai Gain menurut Hake (2012) menunjukkan bahwa nilai gain peningkatan pemahaman siswa mengenai kompetensi anggaran pribadi dengan menggunakan komik edukasi tergolong Sedang.

Hasil penelitian ini menunjukkan bahwa terdapat peningkatan pemahaman siswa mengenai kompetensi anggaran pribadi dengan menggunakan media pembelajaran komik edukasi "Impian Moni”. Hasil penelitian ini menunjukkan hasil yang sama dengan penelitian yang dilakukan oleh Indriana (2012) bahwa penggunaan komik dalam pembelajaran mampu meningkatkan pemahaman siswa.

\section{SIMPULAN DAN SARAN}

\section{Simpulan}

Berdasarkan hasil penelitian dan pembahasan, dapat disimpulkan bahwa:

a. Pengembangan komik edukasi "Impian Moni” dikembangkan dengan model Four-D yang dilakukan melalui 4 tahap yaitu Define, Design, Develop, dan Disseminate.

b. Hasil penilaian komik edukasi oleh para ahli menunjukkan bahwa rata-rata aspek materi sebesar 4,26 (Sangat Layak), aspek aspek media sebesar 3,56 yang dapat dikategorikan "Layak", dan aspek bahasa sebesar 3,9 yang dapat dikategorikan "Layak". Sedangkan respon siswa mengenai komik edukasi "Impian Moni" menunjukkan bahwa skor rata-rata aspek materi sebesar 4,10 yang dapat dikategorikan "Layak", aspek media sebesar 3,89 yang dapat dikategorikan "Layak", dan aspek bahasa sebesar 4,25 yang dapat dikategorikan "Sangat Layak".

c. Peningkatan rata-rata pretest dan posttest adalah sebesar 2,23. Nilai gain skor pretest dan posttest adalah sebesar 0,37 . Peningkatan pemahaman siswa tergolong Sedang.

\section{Saran}

Pengembangan komik edukasi perlu dilakukan untuk materi pembelajaran literasi keuangan lainna. Komik edukasi ini perlu disebar lebih luas agar dapat dimanfaatkan oleh masyarakat untuk mempermudah pembelajaran literasi keuangan.

\section{DAFTAR PUSTAKA}

Atkinson, A., McKay, S., Kempson, E. \& Collard, S. (2006). Levels of Financial Capability in the UK. Results of a Baseline Survey. UK Financial Services Authority (FSA), Consumer Research 47.

Cary, Stephen. (2004). Going Graphic: Comics at Work in the Multilingual Classroom. Heinemann.

Chung Ah Young. (2010). Comic Book Hailed as New Education Tools. Diakses melalui http://www.koreatimes.co.kr/www/news /art/2010/03/135_62659.html pada tanggal 09 September 2015

Fraczek, Bozena. (2014). Main Purposes and Challenges in the Financial Education of Financial Consumers in the World. 
Journal of Economics \& Management. Volume 16.

Hake, Richard. (2012). Analyzing Change/Gain Scores. USA: Indiana University

Hung, A.A., Parker, A.M. \& Yoong, J.K. (2009). Defining and Measuring Financial Literacy. Working Paper. Rand Labor and Population, Rand Corporation.

Huston, S.J. (2010). Measuring financial literacy. The Journal of Consumer Affairs, 44(2), 296-312.

Indriana Mei Listiyani, Ani Widayati. (2012). Pengembangan Komik sebagai Media pembelajaran Akuntansi pada Kompetensi Dasar Persamaan Dasar Akuntansi untuk Siswa SMA Kelas XI. Jurnal Pendidikan Akuntansi Indonesia, Vol. X, No. 2: 80-94.

Klapper, Leora F, Annamaria Lusardi, Georgios A Panos. (2012). Financial Literacy and The Financial Crisis. Working Paper. National Bureau of Economic Research.

Mandell, L. (2009). Starting Younger: Evidence Supporting the Effectiveness of Personal Financial Education for Pre-High School Students. University of Washington and the Aspen.

Mandell, L. (2009). The Impact of Financial Education in High School and College on Financial Literacy and Subsequent Financial Decision Making. Working Paper. San Fransisco: University of Washington.
Organization for Economic Co-operation and Development (OECD). (2005). Improving Financial Literacy: Analysis of Issues and Policies. Paris: OECD.

Orton. (2007). Financial Literacy: Lesson from International Experience. Ontario: Canadian Policy Research Networks Inc.

Otoritas Jasa Keuangan. (2015). OJK Gelar Pasar Keuangan Rakyat di Medan. Siaran Pers Nomor SP84/DKNS/OJK/10/2015

Suiter, M. \& Meszaros, B. (2005). Teaching about saving and investing in the elementary and middle school grades. Social Education, 69 (2), 92 - 95.

Sukarjo. (2005). Evaluasi Pembelajaran IPA. Yogyakarta: Program PPs UNY 